\title{
Role of Individual Academics and International Universities in Health Research
} in Nepal

Simkhada P1-5, van Teijlingen E-8

1Senior Lecturer in International Health, School of Health and Related Research (ScHARR), University of Sheffield, Sheffield.

${ }^{2}$ Honorary Lecturer, University of Aberdeen, UK.

3Visiting Fellow, Bournemouth University, UK.

${ }^{4}$ Visiting Professor, Manmohan Institute of Health Science and Nepal Institute of Health Science, Tribhuvan University, Nepal.

5Visiting Professor, Nobel College, Pokhara University, Kathmandu, Nepal.

${ }^{6}$ Professor, School of Health \& Social Care, Bournemouth University, Bournemouth, UK.

${ }^{7}$ Honorary Visiting Professor, London Metropolitan University, London.

${ }^{8}$ Honorary Professor, University of Aberdeen, UK.

\section{Editorial}

\section{Corresponding Author:}

Dr. Padam Simkhada PhD,

Senior Lecturer in International Health,

School of Health and Related Research (ScHARR),

University of Sheffield, Sheffield. UK.

Email: p.simkhada@sheffield.ac.uk

Health care research is unequally distributed between developed and developing nations, which is matched by unequal distribution of health information ${ }^{1}$. Access to research information is an essential element in strengthening both health sciences and medical practice, and empowering experts in low-income countries like Nepal to find suitable solutions to local health problems and to stimulate evidence-based practice. Evidence-based practice (EBP) is important to help deliver the best quality of care and at the lowest cost. It is very important to have access to most up to date literature in order to be able to practice EBP. However, lack of research literature is the most serious obstacle for health professionals and researchers in lowincome countries. Despite the enormous disease burden in Nepal, research is often viewed as expenditure rather than an investment. Moreover, case studies from Nepal, Bangladesh, and Pakistan report that the bulk of government funding for research goes towards training, salaries and infrastructure, resulting in research projects being largely funded (and influenced) by external donors ${ }^{2}$. Until recently, most health researchers in Nepal worked individually rather than based within institutions.

Nepal has made progress in health sciences and medical education over the past decade. Over 20 medical colleges have already been established and quite a few are being developed. There are more than 100 nursing colleges (both in the private and in the public sector) and many more other colleges run health-related courses (e.g., Public Health, Nursing, Pharmacy and Radiography) in Nepal.

Because of expensive subscription fees and complicated licensed agreements, many medical schools and higher education institutions in Nepal are unable to subscribe to many of the international health and medical journals. Therefore, many Nepali researchers, university teachers 
and research students in the past had little or no access to the global published research literature ${ }^{3}$. Moreover, health research in Nepal is characterised by weak institutional infrastructures, poor funding, the consequent isolation and insularity of a research community where ideas can be exchanged, leading to a poor contribution to the world's knowledge pool. The capacity to absorb scientific, medical and technical knowledge is often weak in Nepal, leading to low levels of scientific output and further underdevelopment.

More recently, due to internationalization and globalization a number of universities from high-income countries are currently working in Nepal. Academics from those institutions are doing research in Nepal, publishing a wide range of scientific articles on health topics related to the country and are providing training to Nepalese academics. These partnerships between Nepalese and overseas universities are often ad-hoc and there is no national strategy for international inter-university collaboration.

We are two of these academics based at UK universities conducting research in Nepal. Over the past eight years we have published nearly 60 scientific papers between the two of us based on research in Nepal, and a substantial proportion has been published in English in Nepal-based journals. In the maternal health field we have been conducting a series of studies on aspects of maternity care in rural Nepal, including antenatal care ${ }^{4-5}$, postnatal care ${ }^{6}$, and costs around birth ${ }^{7}$, to list but a few. In the field of sexual health we have published several papers on the changing attitudes towards sex and sexuality among young people $e^{8-10}$ and the use of sexual health services and condoms of female sex workers in Kathmandu Valley ${ }^{11-12}$.

Many of these papers have been based on student research projects, most, but not all of them, by Nepali MSc or PhD students. The papers on antiretroviral treatment in people living with HIV in $\mathrm{Nepal}^{13-14}$ are an excellent example of good PhD research conducted by Nepali students in the UK as it the work on indoor air pollution ${ }^{15-16}$. Training Nepali MSc and PhD students is helping to build research capacity, but, of course, only if these students came back after their studies.

A few years ago we conducted a bibliographic review of health and medical publications in English of research conducted in Nepal, and the majority of this research was quantitative $^{17}$, which is good for a journal like Nepal Journal of Epidemiology, but like in many low-income countries there is a need for further research capacity building ${ }^{18-35}$. Words like 'capacity building in Nepal' always makes one think of structural changes (the bigger picture), which makes sense on one level as expanding the research capacity in a country require that many people are trained to make a substantial difference at national level. However, the downside of such macro approach is it that it is easy to ignore that individuals can also make some difference.

We believe that there is a need in Nepal for a greater research emphasis on mixed-methods approaches, qualitative research, critical appraisal \& systematic reviewing and health economics. Specifically to the discipline of epidemiology, Nepal should consider establishing more and better epidemiological studies, the kind of population-based studies that can identify risk factors, track changes over time at a population level over the decades to come. We know how important such longterm research is but we are also painfully aware how expensive this kind on long-term research can be.

\section{Conflict of Interests}

The authors have no conflict of interest arising from the study.

\section{References}

1. Katikireddi SV. HINARI: bridging the global information divide. BMJ 2004;328(7449):1190-3.

2. Sadana R, D'Souza C, Hyder AA, Chowdhury AM. Importance of health research in South Asia. BMJ 2004;328(7443):826-30.

3. Arunachalam S. Information for Research in Developing Countries - Information Technology, a Friend or Foe?. Internat Inform Library Rev 2003; 35(2-4): 133-47.

4. Simkhada B, van Teijlingen ER, Porter M, Simkhada P. Major problems and key issues in Maternal Health in Nepal. Kathmandu Univ Med J (KUMJ) 2006;4(2):258-63.

5. Simkhada B, van Teijlingen ER, Porter M, Simkhada P. Factors affecting the utilization of antenatal care in developing countries: systematic review of the literature. J Adv Nurs 2008;61(3):244-60.

6. Dhakal S, Chapman GN, Simkhada PP, van Teijlingen ER, Stephens J, Raja AE. Utilisation of postnatal care among rural women in Nepal. BMC Pregnancy Childbirth 2007;7:19. 7. Simkhada $P$, van Teijlingen E, Sharma G, Simkhada B, Townend J. User costs and informal payments for care in the largest maternity hospital in Kathmandu, Nepal. Health Sci J 2012; 6(2): 317-34. www.hsj.gr/volume6/issue2/ 6212.pdf

8. Regmi PR, Simkhada PP, van Teijlingen ER. "Boys Remain Prestigious, Girls Become Prostitutes": Socio-Cultural Context of Relationships and Sex among Young People in Nepal. Global J Health Sci 2010;2(1): 60-72. Available from: http://ccsenet.org/journal/index.php/gjhs/article/viewFile/ $3951 / 4542$

9. Acharya DR, Bhattarai R, Poobalan A, van Teijlingen ER, 
Chapman G. Factors associated with teenage pregnancy in South Asia: a systematic review. Health Sci J 2010;4 (1): 314. Available from: http://www.hsj.gr/volume4/issue1/ 402.pdf

10. Regmi P, Simkhada P, van Teijlingen ER. Sexual and reproductive health status among young peoples in Nepal: opportunities and barriers for sexual health education and services utilization. Kathmandu Univ Med J (KUMJ) 2008;6(2):248-56.

11. Ghimire L, Smith WC, van Teijlingen ER. Utilisation of sexual health services by female sex workers in Nepal. BMC Health Serv Res 2011;11:79.

12. Ghimire L, Smith WC, van Teijlingen ER, Dahal R, Luitel NP. Reasons for non- use of condoms and self- efficacy among female sex workers: a qualitative study in Nepal. BMC Womens Health 2011;11:42.

13. Wasti SP, Simkhada P, Randall J, Freeman JV, van Teijlingen $\mathrm{E}$. Factors influencing adherence to antiretroviral treatment in Nepal: a mixed-methods study. PLoS One 2012;7(5):e35547.

14. Wasti SP, Simkhada P, Randall J, van Teijlingen E, Freeman J. Barriers to and facilitators of antiretroviral treatment adherence in Nepal: a qualitative study. J Health Pop Nutr (accepted for publication).

15. Kurmi OP, Semple S, Simkhada P, Smith WC, Ayres JG. COPD and chronic bronchitis risk of indoor air pollution from solid fuel: a systematic review and meta-analysis. Thorax 2010;65(3):221-8.

16. Kurmi OP, Devereux GS, Smith WC, Semple S, Steiner MF, Simkhada P, Lam KB, Ayres JG. Reduced lung function due to biomass smoke exposure in young adults in rural Nepal. Eur Respir J 2012 (accepted for publication).

17. Simkhada PP, Baral YR, van Teijlingen ER. Health and medical research in Nepal: a bibliometric review.Asia Pac J Public Health 2010;22(4):492-500.

18. van Teijlingen E, Simkhada P, Ireland J. Lessons learnt from undertaking maternity-care research in developing countries. Evidence-based Midwifery 2010;8(1): 12-16.

19. Sathian B. Future of Clinical Trials in Nepal. Nepal J Epidemiol 2011;1(2): 44-46.

20. Joshi SH, Gupta R, Singh A, Mahajan V. Assessment of immunization Status of Children between 12-23 months in Bareilly District. Nepal J Epidemiol 2011;1(2): 47-50.

21. Sathian B. Methodological Rigors in Medical Journals from Developing Countries: An Appraisal of the Scenario in Asia. Nepal J Epidemiol 2011; 1(5): 141-43.

22. Sathian B, Sreedharan J, Mittal A, Chandrasekharan N, Baboo NS, Abhilash ES, et.al. Case Control Studies in Medical Research. Nepal J Epidemiol 2011;1(3): 77-8.

23. Sathian B. Reporting dichotomous data using Logistic Regression in Medical Research: The scenario in developing countries. Nepal J Epidemiol 2011;1(4):111-113.

24. Sathian B, Sreedharan J, Baboo NS, Sharan K, Abhilash E $S$, Rajesh E. Relevance of Sample Size Determination in Medical Research. Nepal J Epidemiol 2010; 1(1): 4-10.

25. Roy B, Banerjee I, Sathian B, Mondal M, Saha CG. Blood Group Distribution and Its Relationship with Bleeding Time and Clotting Time: A Medical School Based Observational
Study among Nepali, Indian and Srilankan Students. Nepal J Epidemiol 2011;1(4):135-40.

26. Roy B, Banerjee I, Sathian B, Mondal M, Kumar SS, Saha CG. Attitude of Basic Science Medical Students towards Post Graduation in Medicine and Surgery: A Questionnaire based Cross-sectional Study from Western Region of Nepal. Nepal J Epidemiol 2010; 1(4):126-34.

27. Banerjee I, Roy B, Sathian B, Banerjee I, Kumar SS, Saha A. Medications for Anxiety: A Drug utilization study in Psychiatry Inpatients from a Tertiary Care Centre of Western Nepal. Nepal J Epidemiol 2010; 1(4):119-25.

28. Mittal A, Sathian B, Kumar A, Chandrasekharan N, Farooqui MS, Singh S, Yadav KS. Hyperuricemia as an Additional Risk Factor for Coronary Artery Disease: A Hospital Based Case Control Study in Western Region of Nepal. Nepal J Epidemiol 2011;1(3):81-5.

29. Banerjee I, Jauhari AC, Bista D, Johorey AC, Roy B, Sathian B. Medical Students View about the Integrated MBBS Course: A Questionnaire Based Cross-sectional Survey from a Medical College of Kathmandu Valley. Nepal J Epidemiol 2011;1(3): 95-100.

30. Mittal A, Sathian B, Poudel B, Farooqui MS, Chandrasekharan N, Yadav KS. The Significance of Hepatobiliary Enzymes for Differentiating Liver and Bone Diseases: A Case Control Study from Manipal Teaching Hospital of Pokhara Valley. Nepal J Epidemiol 2011;1(5): 153-9.

31. Mittal A, Sathian B, Chandrasekharan N, Lekhi A, Rahib R, Dwedi S. Hepatic Steatosis and Diabetes Mellitus: Risk Factors, Pathophysiology and with its Clinical Implications: A Hospital Based Case Control Study in Western Region of Nepal. Nepal J Epidemiol 2011;1(2):51-56.

32. Banerjee I, Roy B, Banerjee I, Sathian B, Mondol M, Saha A. Depression and its Cure : A Drug Utilization Study from a Tertiary Care Centre of Western Nepal. Nepal J Epidemiol 2011;1 (5):144-52.

33. Mittal A, Sathian B, Kumar A, Chandrasekharan N, Sunka A. Diabetes mellitus as a Potential Risk Factor for Renal Disease among Nepalese: A Hospital Based Case Control Study. Nepal J Epidemiol 2010; 1(1): 22-5.

34. Mittal A, Sathian B, Chandrasekharan N, Lekhi A, Farooqui MS, Pandey N. Diagnostic Accuracy of Serological Markers in Viral Hepatitis and Non Alcoholic Fatty Liver Disease. A Comparative Study in Tertiary Care Hospital of Western Nepal. Nepal J Epidemiol 2011;1(2): 60-3.

35. Mittal A, Sathian B, Kumar A, Chandrasekharan N, Dwedi S. The Clinical Implications of Thyroid Hormones and its Association with Lipid Profile: A Comparative Study from Western Nepal. Nepal J Epidemiol 2010; 1(1): 11-6.

\begin{tabular}{|l|l|}
\hline \multicolumn{2}{|c|}{ Article Information } \\
\hline \multicolumn{2}{|c|}{ Article history } \\
\hline Received & 10 May 2012 \\
Received in revised form & 15 June 2012 \\
Accepted & 20 June 2012 \\
\hline
\end{tabular}

